University of Louisville

ThinkIR: The University of Louisville's Institutional Repository

Electronic Theses and Dissertations

$1-1926$

\title{
Sir Richard Steele, reformer.
}

H. Carter Davidson

University of Louisville

Follow this and additional works at: https://ir.library.louisville.edu/etd

\section{Recommended Citation}

Davidson, H. Carter, "Sir Richard Steele, reformer." (1926). Electronic Theses and Dissertations. Paper 316. https://doi.org/10.18297/etd/316

This Master's Thesis is brought to you for free and open access by ThinkIR: The University of Louisville's Institutional Repository. It has been accepted for inclusion in Electronic Theses and Dissertations by an authorized administrator of ThinkIR: The University of Louisville's Institutional Repository. This title appears here courtesy of the author, who has retained all other copyrights. For more information, please contact thinkir@louisville.edu. 


\title{
UNIVERSITY OF LOUISVIIIE
}

* * Sir richard steeif,REFormer * *

\author{
A Dissertation \\ submitted to the Faculty \\ Of the Graduate School of Arts and Sclences \\ In Partial Fulfillment of the \\ Requirements for the Degree \\ of Master of Arts
}

Department of English

By

H. Carter Davidson, A.B. (Harv.) 
Dedicated to

Professor Dr. E. B. Fowler, the most human teacher of English literature it has yet been my pleasure to meet. 


\section{PREFACE}

Because the critics of the eighteenth century admired form more than thought, Sir Richard Steele has been sady neglected and all honours have been heaped upon his literary partiner,Joseph Addison. Slowly the readers of the twentieth century are beginning to realize that steele had all the originality, while Addison had nothing but polish. It is to present a few of the astoundingly original and influential ideas of Steele that this paper has been written.

To the best of my knowledge after some extended search, the reforms of Richard Steele have not been treated,at least not in the manner nor to the extent with which they are expounded herein. Because of this, the material of my paper has been drawn in the main from a very careful reading of the fifteen hundred papers,plays, and treatises which form Steele's literary heritage. The search has been profoundly interesting, but it has been necessary to plow through many an unrelated subject in order to find a sentence which dealt with reform. The knowlegge gained thereby will, I hope, not be wasted.

It is therefore with the feelings of a returned explorer that I present this report to the vulgar gaze. With it goes the hope that it may lessen the labours of some future student of the eighteenth century. 
The literature of reform is the history of civilization. No vice has ever been eliminated or sublimated without a man to show 1ts viciousness. Athens possessed her socrates, her Zeno, her Dlogenes, and went through constant changes of decline and reformation until her last great reformer, Demosthenes, took poison and accepted defeat. Rome's history is a long line of reforming Brutuses,C1ceros, and Trajans, while her literature numbers among. Its choicest treasures the reforming satires of Lucilius, Horace, and Juvenal. In the Iiterature of France we find Molière, Voltaire, and Rousseau preaching doctrines of reform through the drama, the essay, and the novel. Germanyccan boast of her Luther, Holland her Erasmus, Norway her Ibsen, and Russia her Tolstol, while America is sprouting a thick crop of Menckens, Dreisers, and Sinclair Lewises.

England has always been rife with reform movements. From the time of the Magna Charta to the present day that little island has never been without its new movement. At times it was necessary to behead an unruly monarch in order that the reform might be effected, but in general the people have been amenable to forceful argument and witty satire. In no age of English history was this more true than in the period of the Restoration and the reign of Queen Anne. Defoe, Swift, and a host of others made their kiving by writing pamphlets of attack upon various persons and institutions. There were foibles on every hand to attack, and a ready audience to listen, so what could be more logical than the founding of a little journal, "The Tatler," or the fact that its editor (as we shall realize more clearly when we have studied his life) was Richard steele? 
The birth of this delightful person took place under circumstances which seem to be peculiarly propitious for the production of men of letters, for he himself says, "I am an Englishman born in the city of Dublin." The date is somewhere near March, 1672. His parents left no record, but in Tatler 181 he informs us that the father djed in his son's childhood, and the mother followed soon after, so that sorrow soon entered his life. An uncle guarded him and procured him a position as page to the Duke of Ormond.

Of his schooling we know little, save that he made the friendship of Joseph Addison and gained a very serviceable knowledge of Latin. In 1689 he went up to Christ Church, Oxford, where he acquired la reputation of a student and a good fellow, and supported himself with the revenues from the postmastership of Merton. College and the postmastership could not hold him, however, when there were wars on the continent; so he entered the army as a trooper in 1694. Thackeray has made use of Steele's army career in "Henry Esmond," and Steele made use of it to offer the occasion for his first published poem, The Procession, celebrating the funeral of Mary II.

Very little is known of Steele's life from this time until the publication of the Christian Hero in 1701, but we do know he rose to the rank of captain and acquired a considerable name as a coffee-house notable: The Christian Hero, his first venture into the fleld of reform, is "an Argument proving that No Principles but those of Religion are sufficient to make a Great Man," as the sub-title announces. This he proves from the lives of Cato,Christ, and St. Paul, and winds up with a politic eulogy 
of William III.

Having been dragged into a duel, he wounded his opponent, but thereby crystallized his opposition to the prevalling institution of "satisfaction."

To initiate his vigorous campaign against vice, he wrote, In 1701, a comedy called The Funeral. The story is simpie and farcical. Lord Brumpton, an elderly gentleman, falls into a coma, and is pronounced dead. His young widow immediately makes plans for rejoicings, and secretly makes love to her solicitor. But Lord Brumpton is not dead, and comes to Iife in time to see the duplicity of his wife,to recognize the virtues of his disowned son, Lord Hardy, and to discover the fact that his wife is a polyandrist. Virtue is rewarded, for Lord Hardy is restored to favor and marries his beloved, while the deceitful wife is turned out of the house to go to her first husband. The play is an attack upon the vice of young widows, who wear external signs of deep mourning, while their hearts are joyful and lustful. Some have sald that the play was written to conform to the public taste set up by Jeremy Collier in his "Short View of the Immorality of the English Stage," but I feel that steele's penchant is moralizing, and he needs no urge in that direction.

Two years later The Lying Lover was produced wi.th little success. This play is more moral than its predecessor, for it is an attack upon idle prevarication, fickle love, and duelling. Young Bookwit,just out of Oxford,puts on the airs of a soldier and a dandy, and wins the fickle hearts of Penelope and Victoria. Pene'olpe's betrothed, Lovemore, becomes jealous, challenges Young Bookwit, and is left for dead upon the street. Young Bookwit is arrested and imprisoned, and in prison he suffers a change of 
heart. Penelope, realizing her loss in Lovemore's death, confesses her love for him. But Lovemore is not dead, and the happy ending occurs when he is reconciled to Penelope, while Young Bookwit wins Victoria. The most effective scene in the play is that of Young Bookwit in the prison, for in this steele was probably painting his own experience. The play, as its author said, was "damned for its piety."

In 1705 came The Tender Husband, with scarcely more success. Though the play has some good lines, the plot, one of romantic intrigue, has little moralizing value, and therefore hardly belongs here.

Seventeen years passed before steele again returned to the drama, for in 1707 he was appointed gazetteer, and spent fifteen years in writing the famous series of The Tatler, The snectator, The Guardian, and The Englishman. The reforms whlch he brought forward in these publications will occupy us for the balance of this thesis.

This same period saw Steele a married man, a widower with a handsome estate left by his wife, and again a married man. His connection with the Kit-Gat Glub, his frequent pensions, his constant litigations and struggles with debt, and his final years as a theatrical manager, are hardly within the scope of this peper. Suffice it to say that he died september 1,1729, leaving behind him a place which none other could fill. He has been described by contemporaries as loyal, affectionate, amiable, thoroughly generous and good-hearted, but hopelessly sanguine, restless, and impulsive, to which defects most of his inconsistencles are to be traced.

Before we begin a survey of steele's reforms in his papers, 
we must realize the tremendous value of Joseph Addison's cooperation in the enterprise. True, it was Steele's conception, and it was Steele who kept the papers appearing at regular intervals, but it was Addison who gave them polish, literary flavor, and lasting value. Steele wrote much more than Addison, but the latter's work was very important. Therefore, in order that we may consider steele's work of reform, it has been necessary to ellminate from our study the papers of Addison, Swift,Pope, and other spasmodic contributors.

A careful study of the papers of steele reveals the fact that his reforms fall into six general groups, those dealing with (1) the position of women, (2) soclal vices, (1) political vices, (4) faults of human nature, (5) literature, and (6) general conditions. In the remainder of this paper we shall see what aspects of these subjects he considers, what he says about each, and what effects his arguments had.

It has been said that Richard steele did more for the emancipation of women than any other Englishman, and surely no other man could have defended the fair sex more gallantly or more effectively. He suggested improvements in their condition which have not even yet been realized, and which would be called "ultra-modern" if they were instituted to-day. Some students of his Iife suggest that he was influenced in this work by his deep love for his second wife, but, though all his criticisms are constructive, he did not spate the feelings of the woman-reader. Undoubtedly his paper was as popular with the women as with the men, but it did not pander to the taste of a coquette.

Beginning with the earliest stages of womanhood, Steele attacks the existing forms of female education. This comes 
partly as the result of an appeal from one of these mis-educated misses. Many of the letters published in the "spectator" and "Tatler" were the creations of Steele's own imagination, but we upon

are forced to decidentheir authenticity without conclusive

evidence. Let us at least suppose that this letter comes from a

real person or at least expresses a common opinion (

"It is as much a part of your office to oversee the education of the female part of the nation, as well as of the male; and to convince the world you are not partial, pray proceed to detect the mal-administration of governesses, and rescue our sex from the prejudice and tyranny of education as well as that of your own, who without your seasonable interposition are like to improve upon the vices that are now in vogue."

In answer to this appeal, Sir Richard paints a picture of the evils of the younger generation, and then goes on to say, (Tatler No. 61):

"But these great evils proceed from an unaccountable wild method in the education of the better half of the world, women. We have no such thing as a standard for good breeding. I was the other day at my lady Wealthy's, and asked one of her daughters how she did? She answered 'She never conversed with men,' The' same day I visited at lady Plantwell's, and asked her daughter the same question. She answers, 'What is that to you, you old thief?' and gives me a slap on the shoulders."

We can not help smiling at such conduct towards such a sedate old gentleman as Isaac Blckerstaff, Esquire, must have been. For we must remember that steele felt anonymity the best guise under which to attack the contemporary foibles, and Bickerstaff, the famous creation of Jonathan Swift, served the purpose. The subject, however, is not dropped here,for we find later (Tatler 109):

"I think most of the misfortunes in families arise from the trifling way the women have in spending their time, and gratifying only their eyes and ears, instead of their reason and understanding."

Further on he presents a salution (Tatler 248): 
"Those who are in the quality of gentlewomen should propose to themsèzes some suitable method of passing away their time. This would furnish them with reflections and sentiments proper for the companions of reasonable men, and prevent the unnatural marriages which happen every day between the most accomplished women and the veriest oafs, the worthiest men and the most insignificant females."

Started upon the subject of education, he carries it to

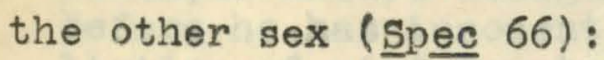

"The general mistake among us in the educating our children is, that in our daughters we take care of their persons and neglect their minds; in our sons, we are so intert upon adorning their minds, that we wholly neglect their bodies. It is from this that you shall see a young lady celebrated and admired in all the assemblies about town; when her elder brother is afraid to come into a room. From this 111 management it arises, that we frequentiy observe a man's life is half spent before he is taken notice of; and a woman in the prime of her years is out of fashion and neglected."

\section{While he is in this predicament he receives a suggestion}

from a feminine hand (spec 53):

"In order to embellish the mistress, you should give a new education to the lover, and teach the men not to be any longer dazzled by false charms and unreal beauty. I cannot but think that ifyour sex knew always how to place their esteem justly, the other would not be so often wanting to themselves in deserving it. For as the being enamoured with a woman of sense and virtue is an improvement to a man's understanding and morals, and the passion is ennobled by the object which inspires 1t; so, on the other side, the appearing amlable to a man of wise and elegant mind, carries in 1 tself no small degree of merit and accomplishments. I conclude, therefore, that one way to make the women yet more agreeable is to make the men more virtuous."

In the accomplishment of this, masculine education also

must be revised, and he suggests (Tatler 173):

"There is an impertinent method of breeding boys without genius or spirit to the reading things for which their heads were never framed. But this is the natural effect of a certain vanity in the minds of parents; who are wonderfully delighted with the thought of breeding their children to accomplishments, which they belleve nothing, but want of the same care in their own fathers, prevented them from being masters of."

This forcing education down unsuited throats he further 
punishment to quicken slow brains ( $\underline{\text { spec }}$ 157):

"But since this custom of educating by the last is suffered by the gentry of Great Britain, I would prevail only that honest heavy lads may be dismissed from slavery sooner than they are at present, and not whipped on to their fourteenth or fifteenth year, whether they expect any progress from them or not. Let the child's capacity be forthwith examined, and he sent to some mechanick way of $11 f e$, without respect to his birth, if nature designed him for nothing higher; let him go before he has innocently suffered, and is debased into a dereliction of mind for being what it is no guilt to be, a plain man. I would not here be supposed to have said, that our learhed men of either robe who have been whipped at school, are not still men of noble and liberal minds; but I am sure they had been much more so than they are, had they never suffered that infamy."

Here we find Steele suggesting two very modern institutions in education, the psychological test to discover vocational tendencles, and vocational education for those incapable of academic work. It was long before these ideas bore fruit, but Steele deserves the credit for planting the seed. Modern education has accepted his principle that physical torture will not aid the understanding, so we can already see one end of which he made the beginning. He outmoderns the moderns in his next suggestion of a method of solving the educational situation ( $\underline{\text { spec }}$ 466):

"You must know no one was ever a good dancer, that had not a good understanding. If this be a truth, I shall leave the reader to judge from that maxim, what esteem they ought to have for such impertinents as fly, hop, caper, tumble, twirl, turn around, and jump over their heads, and, in a word,play a thousand pranks which many animals can do better than a man,instead of performing to perfection what the human figure only is capable of performing. It is from this observation, that I cannot help being so passionate an admirer as I am of good dancing. As all art is an imitation of nature, this is an imitation of nature in its highest excellence, and at a time when she is most agreeable. The business of dancing is to display beauty, and for that reason all distortions and mimickries, as such, are what raise aversion instead of pleasure: but things that are in themselves excellent; are ever attended with imposture and false imitation."

But, he then asks himself and his reader, what is the value 
of all this education to the student? Here we can recognize the

voice of the school-teacher, complaining about his starvation

wages ( Tatler 101):

"However, I may be allowed to speak in the cause of learning itseif, and lament that a liberal education is the only one which a polite nation makes unprofitable. All mechanical artizans are allowed to reap the fruit of their invention and ingenuity without invasion; but he that has separated himself from the rest of mankind, and studied the wonders of the creation, the government of his passions, and the revolutions of the world, and has the ambition to communicate the effect of half his iffe spent in such noble inquiries, has no property in what he is willing to produce, but is exposed to robbery and want, with this melancholy and just reflection, that he is the only man who is not protected by his country, at the same time that he best deserves it."

Having discussed the education of women, and laid down some principles by which it is to be guided, Steele now may turn his attention to their dress. He does not pause to ask himself whether he, a man, is a fit judge of woman's apparel, but he presupposes that women dress to please men, and therefore a vesture which does not please his taste is unsultable. First of all, however, he discusses women's dress in general (Tatler 212):

"Such is the folly of our ladies, that because one who is a beauty, out of ostentation of her being such, takes care to wear something that she knows connot be of any consequence to her complexion; I say, our women run on so heedlessly in the fashion, that though it is the interest of some to hide as much of their faces as possible, yet because a leading toast appeared with a backward head-dress, the rest shall follow the mode, without observing that the author of the fashion assumed it because it could become no one but herself."

Now he turns to a particular fashion which evokes his wrath (Spec 104):

"There is an objection which naturaliy presents itself against these occasional perplexities and mixtures of dress, which is, that they seem to break in upon that propriety and distinction of appearance in which the beauty of different characters is preserved; and if they should be more frequent than they are at present, would look like turning our public assemblies into a general masquerade. The model of this Amazonian hunting-habit for ladies, was, as I take it, first 
imported from France, and well enough expresses the gayety of a people who are taught to do anything so it be with an assurance; but I cannot help thinking it fits awkwardly yet on our English modesty. The petticoat, is a kind of incumberance upon it; and if the Amazons should think fit to go on in this plunder of our sex's ornaments, they ought to add to their spoils, and complete their triumph over us, by wearing the breeches."

And 1o! the Amazons of to-day have followed his sarcastic advice and adopted the masculine riding-breeches. If Gaptain Dick were to behold some of our modern fashions for women, he would probably curse himself for having started them on the path to emancipation. Or, again, would this jolly old trooper mind such a shock upon his modesty? Steele, then, is conservative in his views on women's dress. No man has ever been radical in everything, and steele is only radical in that he is fighting for standards.

Our young lady has now been educated and properly dressed. What would next occupy her busy mind? Love! And now to love we turn our attention, for, as Bickerstaff himself says (Tatler 46):

"Wealth and wisdom are possessions too solemn not to give weariness to active minds, without the relief of wit and love, which are the proper amusements of the powerful and wise."

The predicament of a young lady in love he describes in the following metaphor (Tatier 98):

"A female lover is in the condition of a ghost, that wanders about its beloved treasure, without power to speak, until it is spoken to."

The modern flapper seems to have freed herself from this bondage, also. It is an open question as to whether the following letter would have any effect upon the modern malden, but to the frank Sir Richard, it appears an ideal love letter (Tatler 35):

I know you are very much above the little arts which are frequent in your sex, of giving unnecessary torment to their admirers; therefore I hope you will do so much justice 
to the generous passion I have for you, as to let me have an opportunity of acqualnting you upon what motives I pretend to your good opinion. I shall not trouble you with my sentiments unt 11 I know how they will be recelved; and as I know no reason why difference of sex should make our language to each other differ from the ordinary rules of right reason, I shall affect plainhess and sincerity in my discourses to you, as much as other lovers do perplexity and rapture. Instead of saying, I shall die for you, I profess, I should be glad to lead my life with you: you are as beautiful, as witty, as prudent, and as good-humored as any woman breathing; but I must confess to you, I regard all the se excellences as you will please to direst them for my happiness or misery. With me, madam, the only lasting motive to lave, is the hope of its becoming mutual. I beg of you to inet Mrs. Lucy send me word when I may attend you. I promise you I will talk of nothing but indifferent. things; though, at the same time, I know not how I shall approach you in the tender moment of first seeing you, after this declaration of, madam, your most obedient, and most faithful humble servant, ....-"

We can imagine that this letter is successful, and the courtship begins. Now comes a question of rejected suitors, which Steele treats as follows (Tatler 128):

"A man that is treacherously dealt with in love, may have recourse to many consolatlons. He may gracefully break through all opposition to his mistress, or explain with his rival; urge his own constancy, or aggravate the falsehood by which it is repaid. But a woman that is 11l-treated, has no refuge in her griefs but in silence and secrecy. The world is so unjust, that a female heart which has been once touched, is thought for ever blemished."

Parental interference in affairs of the heart must share the brunt of his attacks (Tatler 185):

"There is no calamity in life that falls heavier upon human nature than a disappointment in love; especially when it happens between two persons whose hearts are mutually engaged to each other. It is this distress which has given occasion to some of the finest tragedies ever written, and daily fills the world with melancholy, discontent, frenzy, sickness, despair, and death. I have of ten admired at the barbarity of parents, who so frequently interpose their authority in this grand article of life."

To deal with these questions of love and feminine life

from the standpoint of the woman, steele created an imaginary

member of the great Staff family, Jenny Distaff. To quote:

"Among the problems of social life which he thus illumined with 
Imagination or even with emotion, none lay nearer steele's own heart than questions of family life. To heighten and illustrate such reflections, he invented a lady editor, Jenny Bistaff, a typical middle class girl, who became the heroine of his domestic sketches."*

This Jenny announces her intentions, but later fails to follow them out. This is characteristic of her creator. But she has brilliant 1deas (TatIer 36):

"While, therefore, the administration of our affairs is in my hands, you shall from time to time have an exact account of all false lovers, and their shallow pretenees for breakingoff; of all termagent wives who make wedlock a yoke; of men who affect the entertainments and manners suitable only to our sex, and women who pretend to the conduct of such affairs as are only within the province of men."

This last phrase makes us wonder what Jenny would have thought of woman's suffrage or female members of parliament. In connection with love, there was opened to steele a great fleld for satire and reform, namely, coquetry. He defines a coquette in no uncertain terms (Tatler 27):

"As a Rake among men is the man who lives in the constant abuse of his reason, so a coquette among women is one who lives - in continual misapplication of her beauty."

He carries the illustration ever farther (Tatler 126):

"The prude and coquette, as different as they appear in their behaviour, are in reality the same kind of women. The motive of action in both is the affectation of pleasing men. They are sisters of the same blood and constitution; only one chooses a grave, and the other a light dress. The prude appears more virtuous, the coquette more vicious, than she really is."

What is to be done to cure such cases? In the ninth Tatler he tells a story of one coquette who was cured by hearine something for her benefit while she was eaves-dropping. All * Cambridge History of English Literature, Vol.IX,p.44. 
such women, however, can not be caught in this manner; so he suggests as follows (Tatler 32):

"This order of Platonic ladies are to be dealt with in a manner peculiar from all the rest of the sex. Flattery is the general way, and the way in this case; but it is not to be done grossly."

But, in his opinion, coquetry is not limited to women. He also has a blow ready for the masculine "fourflusher" (Spec 288):

"Many a man wishes a woman his wife, whom he dares not take for such. Though no one has power over his inclinations or fortunes, he is a slave to common fame. A "fribbler" is one who possesses rapture and admiration for the woman to whom he addresses, and dreads nothing so much as her consent. His heart can flutter by the force of imagination, but cannot fix from the force of judgment."

The mention of love and sexual passion brings to his mind one of the great vices of his age,prostitution. He meets the situation frankly and boldly, attacking the institution from every point of vantage. He sums up the situation (Tatler 5):

"Who names that lost thing, love, without a tear, Since so debauched by 11.1-bred customs here?

To an exact perfection they have brought The action love, the passion is forgot. This was long ago a witty author's lamentation, but the evil still continues; and if a man of anv dellcacy were to attend the discourses of the young fellows of this age, he wand believe there were none but prostitutes to make the objects of passion."

His own sex comes in fortmost of the blame (Tatler 201):

"In the commerce of lovers, the man makes the address, assails, and betrays; and yet stands in the same degree of acceptance, as he was in before he committed that treachery. The woman, for no other crime but believing one whom she thought loved her, is treated with shyness and indifference at the best, and commonly with reproach and scorn."

In the same biting manner he continues (TatIer 199):

"It seems a wonderful inconsistence in the distribution of public justice, that a man who robs a woman of an earring or a jewel, should be punished with death; but one, who by false arts and insinuations should take from her, her very self, is only to suffer disgrace." 
He pleads in very effective fashion for the debauched girl (Spec 266):

"No vice or wickedness, which people fall into from indulgence to desires which are natural to all, ought to place them below the compassion of the virtuous part of the world; which indeed makes me often a little apt to suspect the sincerity of their virtue who are too warmly provoked at other people's personal sins. The unlawful commerce of the sexes is of all other the hardest to avold: and yet there is no one which you shall hear the rigider part of womankind speak of with so little mercy. It is very certain that an honest woman cannot abhor the breach of chastity too much; but pray let her hate it for herself, and only pity it in others."

I fear that if the American women had followed this last piece of advice,prostitution would not have been stamped out so effectively in this country as it has been. Wherein lies the cure for this evil? In marriage, says steele, for (Spec 528):

"The case of celibacy is the great evil of our nation; and the indulgence of the viclous conduct of men in that state, with the ridicule to which women are exposed, though never so virtuous, if long unmarried, is the root of the greatest. irregularities of this nation."

Natura.ly this frank treatment of such a subject evoked some protest upon the grounds of modesty. We find such an opinion volced in letter form (spec 276):

"Mr. Spectator,

I hope you have philosophy enough to be capable of bearing the mention of your faults. Your papers which regard the fallen part of the fair sex, are, I think, written with an indelicacy which makes them unworthy to be inserted in the writings of a moralist who knows the world."

The natural subject to follow this is marriage, so let us now see what attitude the worthy gentleman took toward this old and respected institution. That he held it in the highest respect is shown here ( Tatler 172):

"But there is a relation of life much more near than the most strict and sacred friendship, that is to say, marriage. This union is of too close and delicate a nature to be easily concelved by those who do not know that condition by experience. Here a man should, if possible, soften his passions; 
"if not for his own ease, in compljance to a creature formed with a mind of a quite different make from his own. I am sure, I do not mean it an injury to women, when I say there is a sort of sex in souls. I am tender of offending them, and know it is hard not to do it on this subject; but I must go on to say, that the soul of a man, and that of a woman, are made very unlike, according to the employments for which they are designed."

The value of marriage, and especially of unhampered marriage,

he expounds in the following (Tatler 223):

"The making matrimony cheap and easy would be the greatest discouragement to vice: the limiting the expense of children would not make men 111 inclined, or afraid of having them in a regular way; and the men of merit would not IIve unmarried, as they often do now, because the goodness of a wife cannot be assured to them; but the loss of an estate is certain, and the man would never have the affliction of a worthless heir added to that of a bad wife."

A recent newspaper editorial stated that the greatest. reason for divorces and $v i c e s$ in the wedded state was the ease and cheapness with with marriages are now procured. Lol how the pendulum has swung back to the opposite extreme! But we can not blame steele for solving the problem which faced him, although his method may have been the cause of our present disastrous situation.

The causes of unhappiness in marriage, according to steele, lie in the period before marriage, for (TatIer 199):

"The generality of parents, and some of those of quality, instead of looking out for introducing health of constitution, frankness of spirit, or dignity of countenance into their families, lay out all their thoughts upon finding out matches for their estates, and not for their children."

If the fault does not lie with the parents, it lies with the girl herself, for (Tatlet 91):

\footnotetext{
"When I consider the generality of the female sex, as to their disposals of themselves in marriage, or their parents doing it for them without their own approbation, I cannot but look upon all such matches as the most impudent prostitutions. Wedlock is but a more solemn prostitution, where there is not a union of minds. No married Ilfe could be so unhappy, as where the wife proposes no other advantage from her husband, than that of making herself fine."
} 
The common attitude of women toward the marital state he pictures in an imaginary letter from an authority to a recent bride (Spec 254);

"ipis a little insolence in me,perhaps, to advise a matron, but I am so afraid you'Il make so silly a figure as a fond wife, that I cannot help warning you not to appear in any public places with your husband, and never to saunter about st. James Park together: if you presume to enter the ring at Hide-Park together, you are ruined forever; nor must you take the least notice of each other at playhouse or opera, uhless you would be laughed at for a very loving couple most happily paired in the yoke of wedlock."

His analysis of the masculine attitude toward marriage, and the state of mind in which he enters into that state, follows: (Tatler 149):

"There is nothing so common as for men to enter into marriage, without so much as expecting to be happy in 1t. They seem to propose to themselves a few holidays in the beginning of 1t; after which they are to return at best to the usual courge of their I1fe; and, for aught they know, to constant misery and uneasiness. From this false sense of the state they are soing into, proceed the immediate coldness and indifference, or hatred and aversion, which attend ordinary marriages, or rather bargains to cohabit."

In the same vein, only more bitter, comes a complaint from a defrauded husband (Spec 41):

"I remember in The Sllent Woman, the learned Dr. Cutberd, or Dr. Otter ( $I$ forget which) makes one of the causes of separation to be error personae, when a man marries a woman and finds her not to be the same woman whom he intended to marry, but another. If that be the law, it is, I presume, exactiy my case. For you are to know, Mr. Spectator, that there are women who do not let their husbands see their faces till they are married. Not to keep you in suspense, I mean plainly, that part of the sex who paint."

with marriage in this condition, what remedy is to be suggested? The wives apparently do not respect its duties, nor do the husbands discover its joys. Now we receive what seems to be rank socialism, as a possible solution (Tatler 261):

"There are new proposals for promoting a contribution towards ralsing two hundred and fifty pounds, to be made on the 
"baptising of any infant born in wedlock. The plan is laid with such proper regulations, as serve, to such as fall in with it for the sake of their posterity,all the uses, without any of the inconveniences, of settlements. By this means, such whose fortunes depend upon their own industry, or personal qualifications, need not be deterred, by poverty, from marriage."

This plan was adopted in Germany before and during the last World War, as a method for increasing the fighting power. The next solution of the difficulty which steele suggests is to be seen to-day in France. Whether the idea was original with steele or not is a question, but it is certainly very advanced for the period in which he wrote (Spec 308):

"There wants a rson to be distinguished and vested in the power and quality of a censor on marriages. Now if this be a method founded upon reason and equity, why should there not be also a proper officer for examining such as are entering into the state of matrimony, whether they are forced by parents on one side, or moved by interest only on the other, to come together, and bring forth such awkward heirs as are the product of half love and constrained compliances?"

His broad-mindedness in the case of women is further shown by his attitude toward their legal rights, which were almost nil at the time he wrote (Tatler 84):

"The law to me, Indeed, seems a little defective in this point; and it is a very great hardship, that this crime (rape) which is committed by men only, should have men only on the jury. I humbly, therefore, propose, that on future trials of this sort,half of the twelve may be women."

And from this little seed planted over two centuries ago, has come the modern institution of women on the jury in any and all cases.

But all of his edicts upon women are not commendatory. of the woman's duties he speaks very vehementIy, and upon none more than their duty to their chilaren (spec 246):

"It is unmerciful to see, that a woman endowed with all the perfections and blessings of nature, can, as soon as she is delivered, turn of her innocent, tender, and helpless infant, 
"and give it up to a woman who is neither in health nor good condition, neither sound in mind nor body, that has neither honour nor reputation, neither love nor pity for the poor babe, but more regard for the money than for the whole child, and never will take further care of it than what by all the encouragement of money and presents she is forced to. I beg of $\mathrm{y}$ ou, for the sake of the many poor infants who may and wiIl be saved, by weighing this case seriously, to exhort the people with the utmost vehemence to let the children suck their own mother, both for the benefit of mother and child."

It is now easy to Imagine the effect these daily essays must have had upon the position of women at the time. The men who read the papers were prepared to consider the requests of women when they came, and the women were given a set of rules, ideals, standards, upon which to base their demands. He considered the case of woman from its earliest stages, her education and dress, on through the great problems of her life-love, coquetry,prostitution, and marriage, and finally to her legal privileges and her duty to her children. Every woman who has read the Tatler or spectator must packnowledge her debt to Richard steele.

We must not imagine, however, that steele's success was immediate. He does showsome liope for his work among the women (Tatler 139):

"When I reflect upon the many nights I have sat up for some months last past, in the greatest anxiety for the good of my neighbours and contemporaries, it is no small discouragement to me, to see how slow a progress I make in the reformation of the world. But indeed I must do my female readers the justice to own, that their tender hearts are much more susceptible of good impressions, than the minds of the other sex."

Let us turn now from Steele's work in raising the place of woman to his attacks upon vices which were more general, more masculine. These social vices form his greatest field for attack, and in them he did a tremendous amount of good. 
Due, no doubt, to the fact that the occupations of the better class of Englishmen were limited to war and hunting, there was at this time an over-abundance of duelling. Many of the greatest lords of the realm met death on some dewy field in the chill early hours of the morning, rather than retract some foolish statement made while they were in their cups. No level-headed gentleman of the period could help seelng the folly of the institution, but none dared oppose it openly, in writing, except Richard Steele. We have already seen that a youthful affalr of his own had turned him bitterly against the institution, and had led him to write against it in "The lying Lover." But in the essay form he did more for the elimination of the custom than any other person. No one realizes better than he the difficulties and dangers of his enterprise, for he begins his attack with a statement of them (Tatler 25):

"As it has been proposed to treat of subjects of gallantry in the article from hence, and no one point in nature is more proper to be considered by the company who frequent this place. (White's Chocolate House - the seat of gallantry) than that of duels, it is worth our consideration to examine into this chimerical groundless humour, and to lay every other thought aside, until we have stripped it of all its false pretenses to credit and reputation against men. "But I must confess when I consider what I am going about, and run over in my imagination all the endless crowd of men of honour, who will be offended at such a discourse; I am undertaking, methinks, a work worthy an invulnerable hero in romance, rather than a private gentleman with a single rapier. But I am pretty well acquainted by great opportunities with the nature of man, and know of a truth that all men fight against their w111; the danger vanishes, therefore, and resolution rises upon this subject. For this reason I shall talk very freely on a custom which all men wish exploded, though no man has courage enough to resist it."

He very caustically traces the causes of the ordinary duel (Tatler 25):

"As the matter at present stands, it is not to do handsome actions denominates a man of honour; it is ehough If he dares to defend 111 ones. Most of the quarrels I have 
"known have proceeded from some valiant coxcomb's persisting in the wrong, to defend some prevalling folly, and preserve himself from the ingenuousness of owning a mistake."

The causes of duelling, then, are foolish. Why, then, do sensible men indulge in the vice? This he explains (Spec 84):

"But alas! in the dominions of Pharamond, by the force of a tyrant custom, which is misnamed a point of honour, the duellist kills his friend whom he loves; and the judge condemns the duellist, while he approves his behavious. Shame is the greatest of all evils; what avail laws, when death only attends the breach of them, and shame obedience to them?"

One of Steele's sharpest weapons is burlesque. This he uses with telling effect in the following imaginary loveletter of a duellist to his mistress (Tatler 29):

\section{"Madam -}

I have so tender a regard for you and your interests, that I will knock any man on the head whom I observe to be of my mind, and like you. Mr. Truman, the other day, looked at you in so languishing a manner, that I am resolved to mun him through to-morrow morning. This, I think, he deserves for his guilt in admiring you; than which I cannot have a greater reason for murdering him, except it be that you also approve him. Whoever says he dies for you, I will make his words good, for I will kill him. I am, madam, your most obedient humble servant."

Another method of ridieule which he uses to good effect is the anecdote or vision. In this case he uses the story of his guardian spirit, who describes what happened when he left the body of his former master (Tatler 26):

"At the very instant I was killed, there came away with me a splrit which had lost its body in a duel. We were both examined. Me the whole assembly looked at with kindness and pity, but at the same time with an air of welcome and consolation: they pronounced me very happy. who had died in innocenee; and told me a quite different place was allotted for my companion; there being a great distance from the mansions of the fools and linnocents: though at the same time, said one of the ghosts, there is a great affinity Between an idiot who has been so for a long life, and a child who departs before maturity. But this gentleman who has arrived with you, is a fool of his own making, is ignorant out of choice, and will fare accordingly. The assembly began to flock about him, and one said to him, 'Sir, I observed you came in through the gate of persons murdered, and I desire to know what 
"brought you to jour untimely end.' He said he had been a second. Socrates, who may be sald to have been murdered by the commonwealth of Athens, stood by and began to draw near him, in order, after his manner, to lead him into a sense of his error by concessions in his own discourse. 'sir,' said that divine and amicable spirit, 'what was the quarrel?' He answered, 'We shall know very sudienly when the principal in the business comes, for he was desperately wounded when I fel1.' 'Sir,' said the sage, 'have you an estate?' 'Yes, sir, ' the new guest answered, 'I have left it in a very good condition, and made my will the night before this occasion. 'Did you read it before you signed it?' 'Yes, sure, sir,' said the newcomer. Socrates replies, 'could a man that would not give his estate without reading the instrument, dispose of his $11 \mathrm{fe}$ without asking a question?' That illustrious share turned from him, and a crowd of impertinent goblins, who had been drolls and parasites in their lifetime, and were knocked on the head for their sauciness, came about my fellow traveler and made themselves very merry with questions about the words Carte and Tierce, and other terms of fencers. But his thoughts began to settie into beflection upon the adventure, which had robbed him of his late being; and, with a wretched sigh, sald he, 'How terrible are conviction and sullt when they come too late for penitence!".

His use of Socrates and the socratic method in the

foregoing passage are very effective. The fact that his attacks upon duelling were effective is shown in the

following letter from one of his readers (Tatler 38):

"Dear sir,

The end of all public papers ought to be the benefit and instruction, as well as the diversion of the readers: to which I see none so truly conducive as your late performances; among us, that un-christian-like and bloody custom of duelling; which, that you have already in some measure performed will appear to the public in the following no less true than herolc story. A noble gentleman of this city abused another with the titles of rogue, villain, bearskin-man, and the like. Whereupon satisfaction was demanded, and accepted; so, forth the major marched, commanding his adversary to follow. To a most spacious room in the sheriff's house, near the place of quarrel, they come; where,having due regard to what you have lately published, they resolved not to shed one another's blood, in that barbarous manner you prohibited; yet, not willing to put up affronts without satisfaction, they stripped, and, in decent manner, fought full fairly with their wrathful hands. I am informed, a body of worthy citizens have agreed on an address of thanks to you, for what you have writ on the foregoing subject, whereby they acknowledge one of their highly esteemed offlcers preserved from death." 
Captain steele approves, therefore, of a decision by use of the fists. But his attitude toward ppofessional prizefighters is somewhat different (spec 436):

"There is something in nature very unaccountable on such occasions, when we see the people take a certain painful gratification in beholding these fistic encounters. Is it cruelty that administers this sort of delight? or is it a pleasure which is taken in the exercise of pity?"

An attack upon swearing and profanity may seem useless, but his biting sarcasm here had good use. He imagines his guardian spirit inspecting the brains of men (Tatler 13):

"The next I went to was a common swearer: never was a creature so puzzled as myself, when I first came to view his brain: half of it was worn out, and filled up with mere expletives, that had nothing to do with any other parts of the texture."

Gambling, a very popular vice in that day and this, is attacked after the same fashion (Tatler 13):

"So I went to the next I told you of, the gamester. When we at first take our place about a man, the receptacles of the pericranium are immediately searched. In this I found no one ordinary trace of thinking; but strong passion, violent desires, and a continued serles of different changes, had torn it to pieces. There appeared no middle condition; the triumph of a prince, or the misery of a beggar, were his alternate states."

Steele conducts the reader into a tavern where he points out the vice in 1ts worst aspect (Tatler 15):

"The first thing we took notice of was a nobleman of a goodly and frank aspect,with his generous birth and temper visible in 1t,playing at cards with a creature of a black and horrid countenance, wherein were plainly delineated the arts of his mind, cozenage and falsehood. They were marking their game with counters, on which we could see inscriptions, imperceptible to any but us. My lord had scored with pleces of ivory, or which were writ Good Fame, GIory, RIches, Honor, and Posterity. The spectre over against him had on his counters the inscriptions of Dishonour, Impudence, Poverty, Ignorance, and want of Shame. The young noble is generous to a prodigality, more affable than is consistent with his quality, and courageous to a rashness. Yet,after all this, the source of his whole conduct is (though he would hate himself if he knew it) 
"mere avarice. The ready cash latd before the gamester's counters made him venture, as you see, and lay distinction against infamy, abundance against want; in a word, all that is desireable against all that is to be avoided."

Gambling debts, the inevitable result of such practice,

with their accompaniment of shame, he shows clearly (Spec 82):

"Can there be a more low and servile condition than to be ashamed, or afrald, to see any one man breathing? Yet he that is much in debt,is in that relation to twenty different people. There are indeed circumstances wherein men of honest natures may become liable to debts, by some unadvised behavious in any great point of their life,or mortgaging a man's honesty as security for that of another, and the like; but these instances are so particular and circumstantiated, that they cannot come within general considerations: for one such case as one of these, there are ten, where a man, to keep up a farce of retinue and grandeur within his own house, shall shrink at the expectation of surly demands at his doors."

As soon as tobacco was introduced to English society in the reign of Elizabeth, snuff-taking became the popular rage. No habit could be more disgusting to a person of simple tastes, and Steele condemned 1t without hesitation (Tatler 35):

"There is a habit or custom which I have put my patience to the utmost stretch to have suffered so long, because several of my intimate friends are in the guilt; and that is, the humour of taking snuff, and looking dirty about the mouth by way of ornament. This observation easily led me into a philosophic reason for taking snuff, which is done only to supply with sensations the want of reflection; so when a person feels his thoughts are run out, and he has no more to say, it is as natural to supply his weak brain with powder at the nearest place of access, viz., the nostrils. However low and poor the taking of snuff argues a man to be in his own stock of thoughts, or means to employ his brain and his fingers, yet there is a poorer creature in the world than he, and this is a borrower of snuff; a fellow that keeps no box of his own, but is always asking others for a pinch."

This vice,however, is not Iimited to the masculine sex. In women it is even more disagreeable than in men, and steele does not hesitate to say so (Spec 344):

"I have writ to you three or four times, to desire you would take notice of an impertinent custom the women, the fine women, have lately fallen into, of taking snuff. This silly 
"trick is attended with such a coquet air in some ladies, and such a sedate masculine one in others, that I cannot tell. which most to complain of; but they are to me equally disagreeable."

Having thus bitterly attacked one of the minor personal vices, Steele now becomes the elghteenth century's Pussyfoot Johnson or William Jennings Bryan, and starts an assault upon the ancient English custom of drunkenness. In this he was undoubtedly panderling to the tastes of his women readers, for his advice seems to have had little effect upon those to whom it was directed. To serve as a transfer from his tirade against snuff-taking, he says (Tatler 141):

"These whetters are a people I have considered with much pains; and $f$ ind them to differ froma sect I have hitherto spoken of, called snuff-takers, only in the expedition they take in destroying their brains: the whetter is obliged to refresh himself every moment with a liquor, as the snuff-taker with a powder."

To discourage youngmen from taking up the practice, he makes the following remarks (Tatler 241):

"A method of spending one's time agreeably, is a thing so little studied, that the common amusement of our young gentlemen, especially of such as are at a distance from those of the first breeding, is drinking. This way of entertainment. has custom on 1ts side; but, as much as it has prevalled, I belleve there have been very few companies that have been guilty of excess this way, where there have not happened more accidents which make against, than for the continuance of 1t."

An argument against drinking which might have been used with great effect by any member of the Anti-Saloon League, is set forth in the following paragraph ( Tatler 241):

"Were there only this single consideration, that we are less masters of ourselves, when we drink in the least , proportion above the exigencles of thirst; I say, were this all that could be objected, it were sufficient to make us abhor this vice. But we may go on to say, that as he who drinks but a little is not master of himself, so he who drinks much is a slave to himself." 
vice, so on them his battble-axe falls with double force (Tat 169):

"I have, ever since I could think, been astonished, that drinking should be the vice of the country. If it were possible to add to all our senses, as we do to that of sight by perspectives, we should, methinks, more particularly labour to improve them in the midst of the variety of beauteous objects, which nature has produced to entertain us in the country; and do we in that place destroy the use of what organs we have? As for my part, I cannot but lament the destruction that has been made of the wild beasts of the fleld, when I see large tracts of earth possessed by men who take no advantage of their being rational, but lead mere animal lives; making it their whole endeavour to kill in themselves all they have above beasts, to wit, the use of reason, and taste of society."

And what is the cure? Alas,prohibition is evidently not.

Here is one suggestion (spec 362):

"The chairman at a quarter sessions should inform the country, that the vintner who mixes wine to his customers, shall (upon proof that the drinker thereof died within a year and a day after taking it) be deemed guilty of wilful murder; and the jury shall be instructed to enquire and prevent such delinquents accordingly."

Turning from the destructive attack upon the habit of drunkenness, Steele now attempts to build up a positive and beneficial religion of good works. In spite of the fact that he lived one hundred and fifty years before Challes Darwin, he is constantly confronted with atheists and agnostics. Against these he directs his current of vituperative scorn (

"One gets by heart a catalogue of title-pages and editions; and, immediately to become consplcuous, declares that he is an unbeliever. Another knows how to write a recelpt, or cut up a dog, and forthwith argues against the immortality of the soul. I have known many a little wit, in the ostentation of his parts, rally the truth of the scripture, who was not able to read a chapter in it. These poor wretches talk blasphemy for want of discourse, and are rather the objects of scorm or pity, than of our indignation; but the grave disputant, that reads and writes, and spends all his time in convincing himself and the world that he is no better than a brute, ought to be whipped out of government, as a blot to civil society, and a defamer of mankind."

Now we can see where Bryan procured his thunder! What 
"There is not a more ridiculous animal than an atheist in his retirement. His mind is incapable of rapture or elevation. He can only consider himself as an insignificant figure In a landscape, and wandering up and down in a field or a meadow, under the same terms as the meanest animal about him, and as subject to as total a mortality as they; with this aggravation, that he is the only one amongst them, who lies under the apprehension of 1t. In distresses, he must be of all creatures the most helpless and forlorn; he feels the whole pressure of a present calamity, without being relieved by the memory of anything that is past, or the prospect of anything that is to come."

Nor is he less vituperative in regard to the free-thinker

(Tatler 135):

"There is, indeed, nothing in the world so ridiculous as one of these grave philosophical free-thinkers, that hath neither passions nor appetites to gratify, no heats of blood, nor vigour of constitution, that can turn his systems of infidelity to his advantage, or raise pleasures out of them which are inconsistent with the belief of a hereafter. One that has neither wit, gallantry, mirth, or youth, to indulge by these notions, but only a poor, joyless, uncomfortable vanity of distinguishing himself from the rest of mankind, is rather to be regarded as a mischievous lunatic, than a mistaken philosopher."

But the evil-doer is not to hide from his wrath under the

name of a Christian. He does not hesitate to call most Christians traitors to their faith (Spec 516):

"Of all the monstrous passions and oplnions which have crept into the world, there is none so wonderful as that those who profess the common name of Christians should pursue each other with rancour and hatred for differences in their way of following the example of their saviour. It seems so natural, that all who pursue the steps of any leader should form themselves after his manners, that it is impossible to account for effects so different from what we might expect from those who profess themselves followers of the highest pattern of meekness and charity."

After the same fashion he falls upon the religious

hypocrite, but he finds that "Tartuffe"s are rare in his world

(Tatler 211):

"There are no distinguishing qualities among men to which there are not false pretenders; but though none is more pretended to than that of devotion, there are perhaps fewer successful impostors in this kind than any other. There is something so natively great and good in a person that is 
"truly devout, that an awkward man may as well pretend to be genteel, as a hypocrite to be pious."

The true religion is that of works, says steele, and he makes practical suggestions to his readers how they may live a godly and upright life (Spec 294):

"It is monstrous how a man can live with so little reflection, as to fancy he is not in a condition very unjust, and disproportioned to the rest of mankind, while he enjoys wealth, and exerts no benevolence or bounty to others. As for this particular occasion of these schools, there cannot any offer be more worthy a generous mind."

Sir Richard, then, is a conservative in roligion. He is also

a conservative in the matter of manners (Tatler 21):

"Anyone who is much in company will observe that the height of good breeding is shown rather in never giving offense, than in doing obliging things. Thus he that never shocks you, though he is seldom entertaining, is more $11 \mathrm{kely}$ to keep your favour, than he who often entertains, and sometimes displeases you."

The essentiality of this quality he points out (Tatler 30):

"Hence it is, that wisdom, valour, justice, and learning, cannot keep a man in countenance that is possessed with these excellences, if he wants that infeelor art of life and behavious, called good breeding. A man endowed with great perfections, without this, is like one who has his pockets full of gold, but always wants change for his ordinary occasions."

\section{The purpose of the institution is as follows (Tatler 30):}

"As ceremony is the invention of wise men to keep fools at a distance, so good breeding is an expedient to make fools and wise men equal."

With his customary love of a parablo or fable to clinch his point, Steele introduces a story which shows good breeding in 1ts highest form (Tatler 115):

"It happened one day, as a stout and honest mastiff, that guarded the village where he lived against thieves and robbers, was very gravely walking, with one of his puppies by his side, all the little dogs in the street gathered about him and barked at him. The little puppy was so offended at this affront done to his sire, that he asked him why he would not fall upon them, and tear them to pleces? To which the sire answered, with great composure of mind, "If there were no curs, I should be no mastiff." 
Two particular offenses against good breeding steele points out to his readers. The first (Tatler 89):

"Men never consider whether the sick person be disposed for company, but make their visits to humor themselves. You may talk upon this topic, so as to oblige all persons afflicted with chronical istempers, among which I reckon visits. Do not think me a sour man, for I love conversation and my friends; but I think one's most intimate friend may be too familiar, and that there are such things as unseasonable wit, and painful mirth."

\section{The second is the offense of staring (Spec 20):}

"It has indeed been time out of mind generally remarked, and as often lamented, that this family of starers have infested public assemblies: and I know no other way to obviate so great an evil, except, in the case of fixing their eyes upon women, some male friend will take the part of such as are under the oppression of impudence, and encounter the eyes of the starers wherever they meet them."

With his middle-class broad-mindedness he does not limit this good breeding to the well-born (Tatler 20?):

"The courtier, the trader, and the scholar, should all have an equal pretension to the denomination of gentleman. That tradesman who deals with me in a commodity which I do not understand, with uprightness, has much more right to that character, than the courtier that gives me false hopes, or the scholar who laughs at my ignorance. The appellation of gentlemen is never to be affixed to a man's circumstances, but to his behaviour in them."

He even goes so far as to make good breeding a necessity in art and letters, as is shown in this little extract from the question and answer column (spec 314):

$$
\text { "Sir, }
$$

Pray be so kind as to let me know what you esteem to be the chief qualification of a good poet,especially of one who writes plays; and you will very much oblige, Sir, your very humble servant, N.B.

Ans. To be a very well-bred man.

The spectator."

The antithesis of good breeding he pictures in this description of a rake ( Tatier 27):

"A Rake is a man always to be pitied; and if he lives, is one day certainly reclaimed; for his faults proceed not from 
"cholce or inclination, but from strong passions and appetites, which are in youth too violent for the curb of reason, good sense, good manners, and good nature: all which he must have by nature and education, before he can be allowed to be, or to have been of this order."

Yet the formalism of good breeding can be overemphasized, and a good custom may be abused (spec 6):

"I know of no evil under the sun so great as the abuse of the understanding, and yet there is no one vice more common. It has diffused ltself through all sexes and qualities of mankind; and there is hardly that person to be found, who is not more concerned for the reputation of wit and sense, than honesty and virtue."

Again a custom which is good and appropriate for some people and some occasions may be meaningless and therefore 1nappropriate for others (Spec 64):

"The most improper things we commit in the conduct of our lives, we are led into by the force of fashion. Instances might be given, in which a prevailing custom makes us act against the rules of nature, law, and common sense: but at present I shall confine my consideration of the effect it has upon men's minds, by looking into our behaviour when it is the fashion to go into mourning. The custom of representing the srief we have for the loss of the dead by our habits, certainly had 1ts rise foom the real sorrow of such as were too much distressed to take the proper care they ought of their dress. In process of time this laudable distinction of the sorrowful was lost, and mourning is now worn by heirs and widows. You see nothing but magnificence and solemnity in the equipage of the relict, and an air of release from servitude in the pomp of a son who has lost a weal thy father."

He pictures a ludicrous situation of over-formality when

a squire, judge, and other companions came to visit him (Tatler 86):

"I looked out from my window, and saw the good company all with their hats off, and arms spread, offering the door to each other. After many offers, they entered with much solemnity, in the order $\mathrm{Mr}$. Thrifty was so kind as to name them to me. I had the misfortune, as they stood cheek-by-jowl, to desire the squire to sit down before the justice of the quorum, to the no small satisfaction of the former, and resentment of the latter."

This false delicacy and formality is especially apparent in the matter of eating, and to prove this, steele araws up a 
Iist of the rules by which false-delicates govern their diet and table-manners (Tatler 148):

"The rules amongst these false delicates are to be as contradlctory as they can be to nature.

Without expecting the return of hunger, they eat for an appetite, and prepare dishes, not to allay, but to excite it.

They admit of nothing at their tabies in its natural form, or without some disguise.

They are to eat everything before it comes in season, and to leave it off as soon as it is good to be eaten.

They are not to approve anything that is agreeable to ordinary palates; and nothing is to gratify their senses, but what would offend those of their inferiors."

Back to the good old days! is steele's cry as a solution for the problem (Tatler 148):

"I shall begin with a very earnest and serious exhortation to all my well-disposed readers, that they would return to the food of their forefathers, and reconcile themselves to beef and mutton. As for the flesh of lamb, veal, chlcken, and other animals under age, they were the invention of sickly and degenerate palates. The common people of this kingdom do still keep up the taste of their ancestors; and it is to this that we, in a great measure, owe the unparalleled viotories that have been gained in this reign: for I would desire my reader to consider, what work our countrymen would have made at Blenheim and Ramilies, if they had been fed with fricassees and ragouts."

So have we seen Sir Richard describe, discuss, and attack the leading social vices of the day. We have seen a ppocession passing before us which includes duelling, profanity, gambling, snuff-taking, drunkenness, atheism and anti-Ghristianity, bad breeding, and over-formalism, all vices which seemed inherent in the soclety of the reign of Queen Anne, and which have yet a strong hold upon our social structure. He has suggested cures for some of them, and some of the suggestions have met with success when put into practice, but what can he suggest for vice In general? An evil heart and hand will find an outlet in another place if the first opening is closed. How can the 
this question, not in any one paper, but in the great body of his work. To quote:

"While showing that vice was often concealed under a vell of refinement and liberality, he argued that the young glve way to its allurements from a false idea of manliness or by way of revolt ggainst parental tyranny. The old puritan methods of education had to be softened and humanised. He argued that chlldren could be kept from extravagance and sensuality only by a sense of self-respect and by awakening in them tender memories of a father or mother whom they had learnt to love. He then explains how the parent or guardian must be their companion, and encourage their confidence if he is to understand their characters."*

That Steele realizes the difficulty of his reforming atternt, and that he knows much of his seed has fallen on stony ground, is shown in the following (Tatler 76):

"It is a thing very much to be lamented, that a man must use a certain cunning to caution people agalnst what it is their interest to avoid. All men w1Il allow that it is a great and herolc work to correct men's errors, and, at the price of beine called a common enemy, to go on in being a common friend to my fellow-subjects and citizens. But I am forced in this work to revolve the same thing in ten thousand lights, and cast them in as many forms to come at men's minds and affections, in order to lead the innocent in safety, as well as disappoint the artifices of betrayers. Since, therefore, I can make no impression upon the offending side, I shall turn my observations upon the offended; that is to say, I must whip my children for going into bad company, instead of railing at bad company for ensnaring my children."

Steele's mission was social reform rather than political, but in one or two cases where the social aspect of a political situation engaged his interest, he crossed the boundary. One of these cases whs that of legacies. (In satire he presents a will deeding the estate to the first born. This is not the only attack upon the institution of primogentture made in this age (Tatler 223):

"Therefore, in full and perfect health of body, and a sound mind, not knowing which of my children will prove better 
"or worse, I give to my first born, be he perverse, ungrateful, impious, or cruel, the lump and bulk of $\mathrm{my}$ estate; and leave one year's purchase only to each of my younger chilaren, whether they shall be brave or beautiful, modest or honorable, from the time of the date hereof, wherein I resign my senses."

He comments upon the foolishness of the method of choice for public office (Tatler 41):

"It is not that you are fit for the place, but because the place would be convenient for you, that you claim a merit to it."

Not satisfled with a.tacking the vices of society and human inter-relations, Steele turns himself against the most human of human failings. It has been sald that human nature is not to be changed by laws or arguments, but the brave sir Richard is not to be daunted by such conditions. He is out to reform British society, and if it is necessary to reform the whole human race in so doing, he is ready to undertake the job. He will start in youth and change the nature of man (Tat?er 30):

"The vigilance, the anxiety, the tenderness, which I have for the good people of England, I am persuaded, will in time be much commended; but I doubt whether they will ever be rewarded. However, I must go on cheerfully in my work of reformation: that being my great design, I am studious to prevent my labour's lincreasing upon me; therefore am particularly observant of the temper and inclinations of childhood and youth, that we may not give vice and folly supplies from the growing generation."

The first failing in human nature which meets with his disapproval is affectation, "Showing-off," appearing to be that which one is not. He certainly has not succeeded in curing the human race of that fault, but he has made people laugh at their own fallings, and that is a sure road to reform. Let us first see what quality he desires to find in men (Tatler 86):

"Modesty is the virtue which makes men prefer the public to their private interest, the guide of every honest undertaking, and the great guardian of innocence. It makes men amiable to their friends, and respected by their very enemies. 
"In all places, and on all occasions, it attracts benevolence, and demands approbation."

But modesty is not the outstanding virtue of men, and certainly not of young men (Spec 145):

"There are several of this sort of fellows in town, who wager themselves into statesmen, historians, geographers, mathematiclans, and every other art, when the persons with whom they talk have not wealth equal to their learning. I beg of you to prevent, in these youngsters, this compendious way to wisdom, which costs other people so much time and pains."

So far have some of them gohe, that they cannot boast of Imaginary virtues, so they needs must boast of vices with which they have never had the remotest connection (Tatler 77):

"As bad as the world is, I find by very strict observation upon virtue and vice, that if men appeared no worse than they really are, I should have less work than I am at present obliged to undertake for their reformation. They have generally taken up a kind of inverted ambition, and affect even faults and imperfections of which they are innocent."

This approbation of vice has spread even to the country gentry, who formerly prided themselves upon thelr good solid honesty (Tatler 180):

"The good old way among the gentry of England, to maintain their preeminence over the lower rank, was by their bounty, munificence, and hospitality; and it is a very unhappy change, If at present, by themselves of their agents, the luxury of the gentry is supported by the credit of the trader."

The c1ty-dweller of means considers that his money gives him license to act as he pleases (Tatler 144):

"As the matter now stands, every man takes it in his head, that he has a liberty to spend $h 1 \mathrm{~s}$ money as he pleases. The horses and slaves of the rich take up the whole street: while we peripatetics are very glad to watch an opportunitgy to whisk across a passage, very thankful that we are not run over for interrupting the machine that carries in it a person neither more handsome, wise, or valiant, than the meanest of us."

An example of this "showing-off" by the insignificant men is the misuse of the title esquire (Tatler 19):

"This trusty companion was styled his esquire; and was always fit for any offices about him; was a gentle and chaste 
"as a gentleman usher, quick and active as an equerry, smooth and eloquent as the master of ceremonies. A man thus qualified was the first,as the ancients affirm, who was called an esquire; and none without these accomplishments uoght to assume our order: but, to the utter disgrace and confusion of the heralds, every pretender is admitted into this fraternity, even persons the most foreign to this courteous institution."

The state of English civilization he sums up in the

following words (Tatler 52):

"Thus we see,every man is the maker of his own fortune; and what is very odd to consider, he must in some measure he the trumpeter of his own fame; not that men are to be tolerated who directly praise themselves; but they are to be endowed with a sort of defensive eloquence, by which they shall be capable always of expressing the rules and arts whereby they govern themselves."

Pride of place or of birth nexts recelves the buffets of his scorn. His tenets are clear (Spec 340):

"It is the duty of a great person so to demean himself, as that whatever endowments he may have, he may appear to value himself upon no qualities but such as any man may arrive at: he ought to think no man valuable but for his public spirit, justice and integrity; and all other endowments to be esteemed only as they contribute to the exerting those virtues."

Especially does he find the overweening pride of age in its welght of years and supposed soundness of judgment unbearable and unjustifiable (spec 336):

"The strongest arguments are enervated, and the brightest evidence disappears, before those tremendous reasonings and dazzling discoveries of venerable old age: You are young giddy-headed fellows, you have not yet had experlence of the world. Thus we young folks find our ambition cramped, and our laziness indulged, since, while young, we have little toom to display ourselves; and, when old, the weakness of nature must pass for strength of sense, and we hope that hoary heads will raise us above the attakks of contradiction."

Useless as such an attack may seem, he does not hesitate to inveigh against the petty prevarications of life (Spec 448):

"The first steps towards 117 are very carefully to be avolded, for men insensibly go on when they are once entered, and do not keep up a lively abhorrence of the least unworthiness. There is a certain fritolous falsehood that people indulge themselves in, which ought to be had in greater detestation than it commonly meets with: what I mean is a 
"neglect of promises made on small and indifferent occasions, such as parties of pleasure, entertainments, and sometimes meetings out of curlosity in men of like faculties to be in each other's company."

Flattery of those in high place, one of our most common fallings, next falls under the ban (Spec 480):

"Thus all the words of lordship, honour, and grace, are only repetitions to a man, that the king has ordered him to be called so; but no evidences that there is anything in himself that would give the man who applies to him those ideas, without the creation of his master."

Self-flattery is even worse in its results (spec 282):

"That which produces the greatest part of the pollutions of of mankind, is a false hope which people indulge with so sanguine a flattery to themselves, that thelr hearts are bent upon fantastical advantages which they had no reason to believe should ever have arrived to them. By this unjust measure of calculating their happiness, they of ten mourn with real affliction for imaginary losses."

The evils of avarice are shown clearly in his advice to princes,especlally to Louls XIV. If the "grand monarque" had taken this sound advice,how different modern history might have been! (Spec 180):

"How should there be industry in a country where all property is precarious? That subject w1ll sow his land that his prince may reap the whole harvest? W1Il any man save to-day what he has a reason to fear will be taken from him to-morrow? And where is the encouragement for marrying? Will any man think of raising children without any assurance of clothing for their backs, or so much as food for their bellies?"

Women have no monopoly upon scandal, and men are often inclined to speak evil of their fellow-citizens without cause. This sin of libelling is branded scomfully by Steele (Spec 427):

"Little minds think fame consists in the number of votes they have on their side among the multitude, whereas it is really the inseparable follower of good and worthy actions. Fame is as natural a follower of merit,as a shadow is of a body. It is true, when crowds press upon you, this shadow cannot be seen, but when they separate from around you, it will again appear. Were it not for the pleasure of speaking ill, there are numbers of people who are too lazy to go out of their own houses, and too ill-natured to open their lips in conversation." 
By a deep insight into human nature, Steele discovers the reason for the acceptance of libelling (Tatier 92):

"We reject many eminent virtues if they are accompanied with one apparent weakness. The reflecting after this manner made me account for the strange delight men take in reading lampoons and scandal, with which the age abounds and of which I receive frequent complaints. Upon mature consideration, I find it is principally for this reason, that, the worst of mankind, the libellers, recelve so much encouragement from the world, The low race of men take a secret pleasure in finding an eminent character levelled to their condition by a report of its defects; and keep themselves in countenance, though they are excelled in a thousand virtues, if they believe they have in common with a great person any one fault."

\section{Self-satisfaction and the idleness evolving therefrom}

is described and condemned as follows (Spec 374):

"There is a fault, which, tho common, wants a name. It is the very contrary to procrastination: as we lose the present hour by delaying from day to day to execute what we ought to do immediately; so most of us take occasion to sit still and throw away the time in our possession, by retrospect on what is past, imagining we have already acquitted ourselves, and established our characters in the sight of mankind."

The virago with her fierce scolding must not be passed by without some condemnation (Tatler 217):

"I take the BuIly among men, and the Scold among women, to draw the foundations of their actions from the same defect in the mind. A bully thinks honour consists wholly in being brave; and therefore has regard to no one rule of life if he preserves himself from the accusation of cowardice. The froward woman knows chastity to beethe first merit in a woman, and therefore, since no one can call her one uglyr name, she callis all mankind all the rest."

And now a bit of poetic advice to these viragos how they can make their husbands agreeable (Tatler a):

"Such beauty would the coldest husband warm, But your provoking tongue undoes the charm: Be silent and complying. You'll soon find. Sir John without a med'cine will be kind."

I am sure the Humane Society or the Society for the Prevention of Cruelty to Animals would have presented our author with a medal for the following sentiment (Tatler 134): 
"The virtues of tenderness, compassion, and humanity, are those by which men are distinguished from brutes, as much as by reason itself; and it would be the greatest reproach to a nation, to distinguish itself from all others by any defect in these particular virtues. For which reasons, I hope that my dear countrymen will no longer expose themselves by an effusion of blood, whether it be of theatrical heroes,cocks, or any other innocent animals, which we are not obliged to slaughter for our safety, convenience, or nourishment. When any of these ends are not served in the destruction of a living creature, I cannot but pronounce it but a great plece of cruelty, if not a kind of murder."

Sir Richard possessed that rare quality among men of being able to see both sides of a question. Certainly the servant problem has wrinkled the brows of a thousand generations, but surely no more broad-minded view has been taken of the case than is shown in the two following passages. The first gives the situation from the employer's viewpoint (Spec 88):

"There is no part of the world where servants have those privileges and advantages as in England; they have no where else such plentiful diet, large wages, or indulgent liberty: there is no place wherein they labour less, and yet where they are so little respectful, more wasteful, more negligent, or where they so frequently change their masters."

And wherein lies the cause of this attitude? The question is answered from the servant's angle (Spec 137):

\footnotetext{
"There is something very unaccountable, that people can not put themselves in the condition of the persons below them when they consider the commands they give. But there is nothing more common, than to see a fellow (who, if he were reduced to it, would not be hired by any man living) lament that he is troubled with the most worthless dogs in nature. It would, perhaps, be running too far out of common ilfe to urge, that he who is not master of himself and his own passions, cannot be a proper master of another."
}

Before your eyes has now passed a panorama of the vices of human nature, such as affectation, pride, prevarication, flattery, avarice, libelling, self-satisfaction, scolding, cruelty to dumb beasts, and thoughtless-ness toward servants. Gan we say that it was all in vain? Was there not perhaps one heart brought back to righteousness by this noble preaching? Surely there was some 
truth in these words from a correspondent (Spec 208):

"You are one that doth not only pretend to reform, but effects it among people of any sense."

And yet the uselesshess of these attempted reforms of the nature of man he expresses himself (Tatler 67):

"No man can conceive, until he come to try it,how great a pain it is to be a public-spirited person. I am sure I am unable to express to the world how great anxiety I have suffered, to see of how little benefit my lucubrations have been to my fellow subjects."

Tid Steele suggest and effect these reforms, or was he merely the mouthplece of a great reform movement which was carrying all before it? This latter view is upheld by the best authorities, who say:

"Steele and Addison are writers of talent who rose almost to genius because they intuitively collaborated with the spirit of their age." The time had come when England was weary of all the mediaeval fanaticism, brutality, and prejudice, which had risen to the surface in the civil war. The feud which Greene, a century before, had symbolized as 'a quaint dispute between the velvet breeches and the cloth breeches' had entered upon its last phase. Yotaries of Caroline elegance and dissipation had become a set apart. They still had all the glamor of wealth and fashion; but they had lost their influence on the civilization of the country. The middle blass had broken away from their leadership and had pressed fooward to the front rank of national progress. A new London had sprung up since the great fire, and, with 1t, a generation of Londoners whose temperament and occupations led them to form a standard of culture,honour, and religion peculiar to themselves. The victory of 'cloth breeches' was not complete until steele and Addison had discovered in what quarter 
to look for the movement and in what form to reveal to men their own 1deas." *

But,as students of literature, we are justiy more interested in Steele's literary reforms than in his social reforms. He, however, did not hold the same view. A great deal of the literary reform was entrusted entirely to Addison, who reproduces almost the whole of Paradise Lost in his criticisms of Milton. Steele, however, was not behind-hand in a reformation of general literary evils. He was a constant defender of the classics, an encourager of Shakespearean reading and acting, and an apostle of Milton. For instance, (Tatler 6):

"AIl Milton's thoughts are wonderfully just and natural."

It is especially in the drama, where he did creative and critical as well as managerial work, that we find most of his literary criticisms. We must remember that two of the original four departments of the Tatler were to deal with literature, the Grecian Coffee House having the classics, and Will's dealing with more modern works. In the very first paper we find the drama given a place of impottance (

"On Thursday last was acted, for the benefit of Mr. Betterton, the celebrated comedy called Love for Iove. There has not been known so great a concourse of persons of distinction as at that time. This unusual encouragement, which was given to a play for the advantage of so great an actor, gives an undeniable instance, that the true relish for manly entertainments and rational pleasures is not wholly lost."

He defends the theatre against the charge of immorality so common at this time (Tatler 3):

"I cannot be of the same opinion with my friends and fellow-laborers, the reformers of manners, in their severity 
"towards plays; but must allow, that a good play, acted before a well-bred audience, must raise very proper incitements to good behaviour, and be the most quick and most prevailing method of giving young people a turn of sense and breeding."

In a criticism of Wycherly's "Country Wife" he excuses the rather immoral flavor as follows (Tatler 3):

"A poet had at that time discovered his want of knowing the manners of the court he lived in, by a virtuous character in his fine gentleman, as he would show his ignorance by drawing a vicious one to please the present audience."

The legitimate play receives all his praise; the opera can obtain none. He has no love for music, nor for Italian, as he shows here (Tatler 4):

"Letters from the Hay-market inform us, that on Saturday night last, the Opera of Pyrrhus and Demetrius was performed with great applause. This intelligence is not very acceptable to us friends of the theatre; for the stage being an entertainment of the reason and ail our faculties, this way of being pleased with the suspenge of them for three hours together, and being given up to the shallow satisfaction of the eyes and ears only, seems to artse tather from the degeneracy of our understanding, than an improvement of our divisions. That the understanding has no part in the pleasure is evident, from what these letters very positively assert, to wit, that a great part of the performance was done in Italian."

The dramatic taste of London he considers a terrible tribulation for the actors (Tatier 8):

"Of aIl men IIving I pity players that they are obliged to repeat and assume proper gestures for representing things of which their reason must be ashaned and which they must disdain their audience for approving. The amendment, of these low gratifications is only to be made by people of condition, by encouraging the representation of the noble characters drawn by Shakespeare and others, from whence it is impossible to return without strong impressions of honour and humanity. On these occasions, distress is laid before us with all its causes and consequences, and our resentment placed according to the merit of the persons afflicted. Were dramas of this nature more acceptable to the taste of the town, men who have genius would bend their studies to excel in them."

To prove that steele believed in the conscientious reproduction of dramatic works, it is only necessary to quote this passage (Tatler 89): 
"There is nothing more ridiculous than for an actor to insert words of $\mathrm{his}$ own in the part he is to act, so that it is impossible to see the poet for the player."

One of the more definitie objects of his attacks is the writing of meaningless dedications (Tatler 177):

"Were it granted that praises in dedications were proper topics, what is it that gives a man authority to commend, or what makes it a favour to me that he does commend me? It is certain, that there is ho praise valuable but from the praiseworthy."

Punning, even more common then than it is now, calls down his wrath (Tatler 32):

"The evils of this town Increase upon me to so great a degree, that I am half afraid. I shall not leave the world better than I found it. Several worthy gentlemen and critics have applied to me,to give my censure of an enormity which has been revived, after being long suppressed, arid is called punning. I have several arguments ready to prove that he cannot be a man of honour, who is guilty of this abuse of human society."

\section{Continuing in the same vein (Spec 504):}

"That which we call punning is greatly affected by men of small intellects. These men need not be concerned with you for the whole sentence, but if they can say a quaint thing, or bring in a word which sounds like any one word you have spoken to them, they can turn the discourse, or distract you so that you cannot go on, and, by consequence, if they cannot be as witty as you are, they can hinder you being any wittier than they are."

Being an author who published some books, steele naturally

is a fighter for some sort of copyright on his works. Book pirates are to him the scum of the earth (Tatler 101):

"These miscreants are a set of wrtches we authors call pirates, who print any book, poem, or sermon, as soon as it appears in the world, in a smaller volume; and sell it, as all other thieves do stolen goods, at a cheaper rate. I was in my rage calling them rascals, plunderers, robbers, highwaymen. But they acknowledge all that, and are pleased with those, as well as any other titles; nay, will print them themselves, to turn the penny."

The plagiarist is a criminal of the same color (spec 546):

"All that I was going to say about the honesty of an author in the sale of his ware was, that he ought to own all 
"that he had borrowed from others, and lay in a clear light all tnat he gives his spectators for their money, with an account of the first manufacturers."

In his reform of literary style, he accomplished more by example than by precept. We can all remember how Franklin rewrote the spectator in order that he might attain a strle, or how Stevenson worked night and day to acquire the polish of Steele and Addison. There was a good background for this change in style in the conversation of the time, as it has been clearly shown :

"The Royal soclety had already started a movement against redundance of phrase; but it may weIl be doubted whether the protests of Pratt,Evelyn, and South would have had lasting effect without the influence of coffee-houses. The man who has formed his mind by intercourse is more versatile and alert than he whose intellect has grown by reading, and he has learnt to speak in short simple sentences, because the ear cannot,like the eye, follow long periods. Moreover, he must abandon the phraseology of books, because the written word had long assumed a formal, almost impersonal, air, and must borrow turns and phrases from daily parlance to give an individual tough to his theories."*

Steele, therefore, was working for a concise, precise style, which requires careful handling (Tatler 9):

"Instead of such agreeable works as these, the town has for half an age been tormented with Insects called Easy Writers, whose abilities Mr, Wycherly one day described excellently well in one word: "That,' says he, 'among these fellows is called easy writing, which anyone may easily write:"

He is not content, however, to allow the style of the coffee- 
house to dominate the style for writing (Tatler 62):

"But there is a wit for discourse, and a wit for writing. The easiness and familiarity of the first is not to savour in the least of study; but the exactness of the other is to admit of something like the freedom of discourse,especially in treatises of humanity, and what regards the belles lettres."

William Dean Howells would probably have declared that the realist movement in literature began with the following passage (Tatler 172):

"Instead of such high passages, I was thinking it would be of great use, if any body could hit it, to lay before the world such adventures as befal persons not exalted above the common level. This, methought, would better prevall upon the ordinary race of men; who are so prepossessed with outward appearances, that they mistake fortune for nature, and believe nothing can relate to them, that does not happen to such as live and look like themselves."

Yet he is most emphatically not a preacher of naturalism or sadism, for he says (Tatler 108):

"I could never read any of our modish French authors, or those of our own country, who are the imitators and admirers of that trifling nation, without being for some time out of humour with myself, and at everything about me. Their business is, to depreciate human nature, and consider it under its worst appearances."

One of the greatest services which steele rendered in the literary world was that of turning the attention of readers to the moral qualities of literature. It has been authoritatively sald:

"At a time when the most enlightened critics admired a poet for his rhetoric, Steele discpvered in Shakespeare and Milton the sublime moralists of middle-class life,quoting from their pages to show where the everyday virtues of fidelity,pityr and conjugal Iove have found their purest and noblest expression. He does not, however, seek to impress this view on his public. He never taught his readers how to, look for moral and spiritual 
guidance in literature. They are left to glean what they can from chance utterances. Had it been otherwise, these papers would have been the most remarkable critical production of Steele's generation." *

To turn now from the more specifically literary reforms to the general reforms before we close,we must first asks what in society and life was the central object of his attacks. The answer to this is found in his own words, (Tatler 12):

"You are to understand that simplicity of behaviour which is the perfection of good breeding and good sense, is utterly lost in the world; and in the room of it there are started a thousand little inventions, which men,barren of better things,take up in the place of it."

$\mathrm{He}$ is striving, then, for a return to simplicity in behaviour. Of course the greatest obstacle to this reform was countenanced vice. Therefore we find most of his bitterest attacks directed against this bulwark (Tatler 191):

"Of all the evils under the sun, that of making vice commendable is the greatest; for it seems to be the basis of society, that applause and contempt should be always given to proper objects. But in this age we behold things, for which we ought to have an abhorrence, not only recelved without disdain, but even valued as motives of emulation. This is naturaliy the destruction of simplicity of manners, openness of heart, and generosity of temper."

He defends himself from the charge of muck-raking in the following terms (Spec 286):

"True delicacy, as I take it,consists in exactness of judgment and dignity of sentiment, or if you will, purity of affection,as this is opposed to corruption and grossness. There are pedants in breeding as well as in learning. The eye that cannot bear the light is not delicate, but sore. A good constitution appears in the soundness and vigour of the parts, not in the squeamishness of the stomach; and a false delicacy is affectation, not politeness. What 
"then can be the standard of delicacy but truth and virtue?"

But at the same time he can reveal the faults of the

critic with equal frankness (Tatler 29):

"It j.s a particular observation I have always made, that of all mortals a critic is the silliest; for,by enuring himself to examine all things, whether they are of consequence or not, he never looks upon anything but with a design of passing sentence upon it; by which means he is never a companion, but always a censor. This makes him earnest upon trifles, and dispute on the most indifferent occasions with vehemence."

The reasons for all of his reforming work, and the reasons for his discontinuing it, are summed up in a few words (Tatler 271):

"The general purpose of the whole has been to recommend truth, innocence, honour, and virtue, as the chief ornaments of life; but I considered, that severity of manners was absolutely necessary to him who would censure others, and for that reason, and that only, chose to talk in a mask. I shall not carry my humility so far as to call myself a vicious man, but at the same tine must confess, my life is at best but paraonable. And, with no greater character than this, a man would make but an indifferent progress in attacking prevaling and fashionable vices, which $\mathrm{Mr}$. Bickerstaff has done with a freedom of spirit, that would have lost both its beauty and efficacy, had it been pretended to by $\mathbf{M r}$. Steele."

And now, as a result of all these attempts at reform, what reward awaits the hero? Nought but debts in the world of facts, and in the minds of future generations a place subordinate to his assistant. If this paper has done no more than make one mind acknowledge the genius of Sir Richard Steele,it has fustified its existence. I am sorely tempted to close in a eulogy of that brave man,but I could find no better one than that which closes the Spectator (Spec 532):

"In courts licentious, and a shameless stage, How long the war shall wit with virtue wage? Enchanted by this prostituted fair, Our youth run headlong in the fatal snare: In height of rapture clasp unheeded pains, And suck pollution through their tingling veins. Thy spotless thoughts unshocked the priest And the pure vestal in her bosom may hear, 
"To conscious blushes, and diminished pride, Thy glass betrays what treacherous love would hide; Nor harsh thy precepts, but infus'd by stealth, Please while they dure, and cheat us into health. Thy works in Chloe's toilet gain a part, And with his tallor share the fopling s heart: Lash'd in thy satyr, the penurious cit-Laughs at himself, and finds no harm in wit: From felon gamesters the raw squire is free, And Britain owes her rescued oaks to thee. His miss the frolic viscount fears to toast, Or his third cure the shallow Templar boast; And the rash fool, who scorned the beaten road, Dares quake at thunder, and confess his God. The brainless, stripling, who, expelled to town, Damn'd the stiff college and pedantick gown, Aw'd by thy name, is dumb, and thrice a week Spells ancouth Latin, and pretends to Greek. A sauntring tribel such born to wide estates, With Yea and No in senates hold debates: At length despised,each to his fields retires, First with the dogs, and King amidst the squires: From pert to stupid sinks supinely down, In youth a coxcomb, and in age a clown. Such readers scorned, thou wingst thy daring flight Above the stars, and tread'st the fields of light: Fame, Heaven, and Hell are thy exalted theme, And visions such as Jove himself might dream." 


\section{BIBLIOGRAPHY}

The Tatler - complete in 271 papers. Cincinnat1,1860. The Spectator - complete in eight volumes and 635 papers. E.P.Dutton \& Co.,New York, 1917.

The Guardian - complete in 175 papers. Cincinnati,1860. The Plays of Sir Richard Steele - (Mermaid Series) complete $1 \times x 1$ f 452 pages. New York 1920. (Edited by G.A.Aitken).

The Christian Hero - pamphlet reprint,Boston, 1810. Richard Steele - in "Inglish Worthies" series. by Mustin Dobson. $240 \mathrm{pp}$. New York, 1886 .

Life of Richard Steele - G.A.Aitken. 2 vols. New York 1910 The English Humorists - W.M.Thackeray. Essay on Steele. Cambridge History of English Literature - Vol. IX. In addition innumerable shorter histories of English literature, including Edmund Gosse,George Saintsbury, Henry S. Pancoast, Neilson and Thørndike, Thomas Arnold, and Leslie Stephen. For a picture of the times,Ashton's "Social Life in the Reign of Queen Anne" was read. 